\title{
Characteristics of tuberculosis in the state of Minas Gerais, Brazil: 2002-2009*
}

\author{
Características da tuberculose no estado de \\ Minas Gerais entre 2002 e 2009
}

\author{
Cláudio José Augusto, Wânia da Silva Carvalho, Alan Douglas Gonçalves, \\ Maria das Graças Braga Ceccato, Silvana Spindola de Miranda
}

\begin{abstract}
Objective: To analyze the profile of tuberculosis cases reported between 2002 and 2009 in the state of Minas Gerais, Brazil, according to sociodemographic, clinical, and laboratory characteristics, as well as to comorbidities and mortality. Methods: This was a descriptive, epidemiological study based on data obtained from the Brazilian Case Registry Database and the Brazilian Mortality Database for the 2002-2009 period. Results: There were 47,285 reported cases of tuberculosis, corresponding to a mean incidence of 22.3/100,000 population. The individuals diagnosed with tuberculosis were predominantly in the 20- to 49-year age bracket and male (62.4\% and $67.0 \%$, respectively). Individuals with a low level of education accounted for $18.5 \%$ of the cases. New cases, cases of recurrence, and cases of retreatment accounted for 83.7\%, 5.7\%, 5.7\%, respectively. The rates of cure and treatment noncompliance were $66.2 \%$ and $11.2 \%$, respectively; multidrug-resistant tuberculosis was identified in $0.2 \%$ of the cases; and the mortality rate was $12.9 \%$. The directly observed treatment, short-course (DOTS) strategy was applied in $21.8 \%$ of the cases. Sputum smear microscopy and culture were performed in only $73.9 \%$ and $12.9 \%$ of the cases, respectively. Chest X-rays were performed in $90.5 \%$ of the cases. Pulmonary tuberculosis was the predominant form (in 83.9\%). Comorbidity with alcoholism, HIV infection, and diabetes mellitus were identified in 17.2\%, 8.3\%, and 3.8\%, respectively. Conclusions: During the study period, the numbers of new cases, cases of treatment noncompliance, and deaths were high, comorbidities were common, and there was a failure to perform adequately basic tests for the diagnosis of tuberculosis. Multidisciplinary approaches, expanded use of the DOTS strategy, better knowledge of the distribution of tuberculosis, and improvements in the databases are needed in order to achieve better control of the disease in the state of Minas Gerais.
\end{abstract}

Keywords: Tuberculosis/epidemiology; Tuberculosis/mortality; Information systems.

\section{Resumo}

Objetivo: Analisar o perfil de casos de tuberculose no estado de Minas Gerais entre 2002 e 2009, segundo características sociodemográficas, clínicas e laboratoriais, assim como presença de comorbidades e mortalidade. Métodos: Estudo epidemiológico descritivo com levantamento de dados dos casos notificados no Sistema de Informação de Agravos de Notificação e Sistema de Informação de Mortalidade entre 2002 e 2009. Resultados: Foram notificados 47.285 casos de tuberculose nos anos estudados, com média de incidência 22,3/100.000 habitantes. Os indivíduos com tuberculose eram predominantemente da faixa etária de 20-49 anos $(62,4 \%)$, do sexo masculino $(67,0 \%)$ e tinham baixa escolaridade (18,5\%). Casos novos, de recidiva e de retratamento representaram, respectivamente, 83,7\%, $5,7 \%$ e $5,7 \%$ do total de casos. As proporções de cura, abandono do tratamento e tuberculose multirresistente foram, respectivamente, $73,1 \%, 11,2 \%$ e $0,2 \%$, enquanto o coeficiente de mortalidade foi $12,9 \%$. 0 tratamento diretamente observado (TD0) foi administrado em 21,8\% dos casos. A baciloscopia e a cultura de escarro somente foram realizadas em 73.9\% e 12,9\% dos casos, respectivamente. A radiografia de tórax foi realizada em $90,5 \%$ dos casos. A forma pulmonar prevaleceu (83,9\%). A comorbidade com alcoolismo, infecção pelo HIV e diabetes mellitus foi identificada em 17,2\%, 8,3\% e 3,8\% dos casos, respectivamente. Conclusões: No período estudado, o número de casos novos, de abandono e de óbitos foi elevado, as comorbidades foram relevantes, e os exames básicos não foram realizados adequadamente para o diagnóstico da tuberculose. São necessários o trabalho multiprofissional, ampliação da estratégia TDO, maior conhecimento da distribuição da tuberculose em Minas Gerais e melhorias nos bancos de dados para que haja um melhor controle da doença no estado.

Descritores: Tuberculose/epidemiologia; Tuberculose/mortalidade; Sistemas de informação.

\footnotetext{
* Study carried out at the Federal University of Minas Gerais, Belo Horizonte, Brazil.

Correspondence to: Silvana Spindola de Miranda. Faculdade de Medicina, $2^{\circ}$ andar, Departamento de Clínica Médica, Avenida Alfredo Balena, 190, Santa Efigênia, CEP 30130-100, Belo Horizonte, MG, Brasil.

Tel. 5531 3248-9599. E-mail: spindola@medicina.ufmg.br

Financial support: This study received financial support from the Fundação de Amparo à Pesquisa do Estado de Minas Gerais (FAPEMIG, Foundation for the Support of Research in the state of Minas Gerais).

Submitted: 11 November 2012. Accepted, after review: 1 February 2013.
} 


\section{Introduction}

Even with the advancement of medicine, tuberculosis remains the infectious disease that causes the greatest number of deaths among adults worldwide. It is estimated that one third of the world population is infected with Mycobacterium tuberculosis and that, each year, the bacillus makes approximately 9.4 million people ill, causing 1.7 million deaths. In 2009 in Brazil, there were 71,686 reported new cases and approximately 4,800 reported deaths, which means that Brazil ranks 19th among the 22 countries that are estimated to account for $80 \%$ of all cases of tuberculosis worldwide. ${ }^{(1,2)}$

In recent years, the Brazilian National Ministry of Health has encouraged tuberculosis control, on the basis of the targets set by the World Health Organization (WHO): diagnose at least 70\% of the expected cases; properly treat $100 \%$ of the diagnosed cases; cure at least $85 \%$ of those cases; and maintain treatment noncompliance at acceptable levels (up to 5\%). Among the Brazilian states, Minas Gerais ranks 5th in terms of the number of reported cases. ${ }^{(2)}$

Minas Gerais is one of the 27 federative units in Brazil and has a territorial extent of 586,528.29 $\mathrm{km}^{2}$. With a population of $19,595,309$ people, it is the second most populous state in Brazil, with a population density of 32.73 people $/ \mathrm{km}^{2}$ and 853 cities. The cities in the state of Minas Gerais account for $51.5 \%$ of the cities in southeastern Brazil and for 15.5\% of the cities in Brazil. The state is subdivided into 28 Regional Health Management Districts and currently has 25 priority cities for tuberculosis control. In addition, Minas Gerais has 3,553 Family Health Program Teams, who serve 829 cities. $^{(3,4)}$

Some diseases can favor the development of tuberculosis. The three chief comorbidities among those related to tuberculosis are HIV infection, alcoholism, and diabetes mellitus (DM). The epidemiological profile of tuberculosis has been changed by HIV over the years. Tuberculosis/HIV co-infection has caused an increase in mortality, changing resistance to antituberculosis drugs and the risk of transmission due to treatment noncompliance. . $^{(5,6)}$

Studies have shown that DM can favor the development of tuberculosis and account for over 10\% of tuberculosis cases due to immunosuppression, and that the risk of developing tuberculosis is approximately three times higher in patients with DM than in those without. ${ }^{(7,8)}$ This therefore justifies the need for increasing efforts to identify and treat diabetic patients with latent $M$. tuberculosis infection before the disease becomes active. ${ }^{(7,9)}$ Alcoholism is also associated with pulmonary tuberculosis, leading to a higher risk of developing the disease and to treatment difficulties. ${ }^{(10)}$

Given this context, knowledge of the characteristics of tuberculosis could contribute to the development of new strategies for the control of this disease in accordance with the targets set by the WHO. Therefore, the objective of the present study was to analyze the profile of tuberculosis between 2002 and 2009 in the state of Minas Gerais according to sociodemographic, clinical, and laboratory characteristics, as well as to comorbidities and mortality.

\section{Methods}

This was a descriptive, epidemiological study based on data regarding reported cases of tuberculosis by city of residence obtained from the Brazilian National Ministry of Health Sistema de Informação de Agravos de Notificação (SINAN, Brazilian Case Registry Database) for the 2002-2009 period in the state of Minas Gerais. The present study was approved by the Ethics Committee of the Federal University of Minas Gerais (Protocol no. ETIC 216-08).

All cases reported in the period were included, and 341 cases were excluded because of missing or unknown data, such as age, gender, city of residence, and previous treatment.

Incidence, defined on the basis of the tuberculosis cases registered in the SINAN, was calculated by dividing the mean rate of new cases of tuberculosis by the mean population estimate.

We analyzed sociodemographic characteristics (gender, age, and level of education), clinical characteristics (disease form, type of admission, and outcome), and laboratory characteristics (sputum smear microscopy results, sputum culture results, chest $\mathrm{X}$-ray findings, and tuberculin skin test [TST] results), as well as comorbidities (HIV infection, DM, and alcoholism). The reference values used for the analysis of the TST results were as follows: negative, an induration of 0 to $4 \mathrm{~mm}$; weakly positive, an induration of 5 to 9 $\mathrm{mm}$; and strongly positive, an induration $\geq 10$ $\mathrm{mm},{ }^{(11)}$ as described in the SINAN. 
Data on the population (per 1,000 people) were obtained from the Brazilian Institute of Geography and Statistics, according to estimates and the 2010 census. ${ }^{(3)}$

The analysis of the clinical characteristics involved disease form (pulmonary, extrapulmonary, and disseminated forms), type of (new case, recurrence, readmission after treatment noncompliance, and transfer), and outcomes (cure, treatment noncompliance, transfer, a change in diagnosis, multidrug-resistant (MDR) tuberculosis, and death). Mortality data were obtained from the Sistema de Informação de Mortalidade (SIM, Brazilian Mortality Database).

The data obtained were entered into a database with the use of TabWin 3.5, which is made available by the Information Technology Department of the Brazilian National Ministry of Health, and the analyses were performed with the Statistical Package for the Social Sciences, version 16.0 (SPSS Inc., Chicago, IL, USA), and OpenEpi, version 2.3. We performed a descriptive analysis of the information obtained from this database, including a description of the population, frequency distributions, and statistical measures of the selected characteristics. Interval estimation was performed by using confidence intervals for binomial proportions based on the Wilson test score method. ${ }^{(12)}$

\section{Results}

During the study period, there were 47,285 reported cases of tuberculosis. The mean incidence rate was 22.3/100,000 population (Figure 1).

The 20- to 49-year age group had the greatest number of tuberculosis cases, which corresponds to 29,526 cases $(62.4 \%)$, followed by the over65 -year age group (5,356 cases; 11.3\%). Males predominated (31,690 cases; $67.0 \%$; Table 1$)$.

Regarding the level of education, those who had had less than 9 years of schooling had the highest incidence (9,288 cases; 18.5\%), followed by those who had had less than 5 years of schooling (8,267 cases; $16.5 \%$; Table 1$)$.

Regarding the type of admission, the distribution was as follows: new case, in 39,581 cases (83.7\%); recurrence, in 2,686 cases (5.7\%), readmission after treatment noncompliance, in 2,697 cases (5.7\%); transfer, in 1,980 cases (4.2\%); and no data, in 341 cases (0.7\%; Figure 2).

The directly observed treatment, short-course (DOTS) strategy was applied in 10,317 cases $(21.8 \%)$.

Of the reported cases, $53.8 \%$ had a positive first sputum smear and 26.1\% did not undergo sputum smear microscopy. Of the patients who underwent culture, 2,743 (66.7\%) had positive results. However, 41,227 patients (87.1\%) did not undergo the test. Chest X-rays were performed
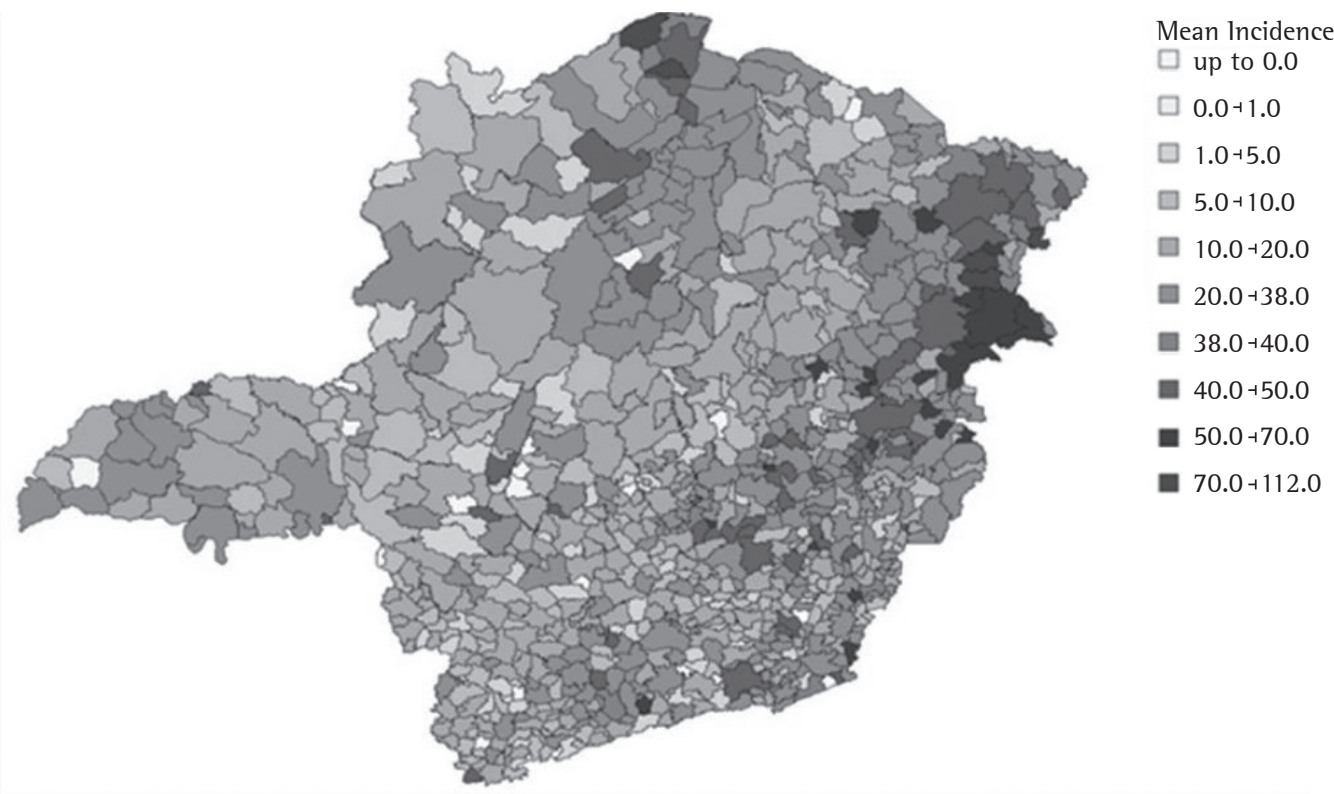

Figure 1 - Spatial distribution of the mean incidence of tuberculosis in the state of Minas Gerais, Brazil, by city, 2002-2009. Source: SINAN-MG (Brazilian Case Registry Database-Minas Gerais). 
in $42,343(89.5 \%)$ of the reported cases, and 38,495 ( $81.4 \%$ of the total number of cases) were considered to be cases of suspected tuberculosis.

Table $\mathbf{1}$ - Frequency of tuberculosis by age bracket, gender, and level of education, Minas Gerais, Brazil, 2002-2009.

\begin{tabular}{|c|c|c|c|}
\hline Variable & $\mathrm{n}$ & $\%$ & $95 \% \mathrm{Cl}$ \\
\hline \multicolumn{4}{|l|}{ Age bracket, years } \\
\hline$<1$ & 266 & 0.6 & $0.5-0.7$ \\
\hline $1-4$ & 356 & 0.7 & $0.6-0.8$ \\
\hline $5-9$ & 420 & 0.9 & $0.8-1.0$ \\
\hline $10-14$ & 549 & 1.2 & $1.1-1.3$ \\
\hline $15-19$ & 2,055 & 4.3 & $4.2-4.5$ \\
\hline $20-34$ & 13,757 & 29.0 & $28.7-29.5$ \\
\hline $35-49$ & 15,769 & 33.4 & $32.9-33.8$ \\
\hline $50-64$ & 8,757 & 18.5 & $18.2-18.9$ \\
\hline $65-79$ & 4,286 & 9.1 & $8.8-9.3$ \\
\hline$\geq 80$ & 1,070 & 2.3 & $2.1-2.4$ \\
\hline \multicolumn{4}{|l|}{ Gender } \\
\hline Male & 31,690 & 67.0 & $66.6-67.4$ \\
\hline Female & 15,595 & 33.0 & $32.6-33.4$ \\
\hline \multicolumn{4}{|l|}{ Level of education } \\
\hline Illiterate & 4,097 & 8.7 & $8.4-8.9$ \\
\hline $\begin{array}{l}\leq 9 \text { years of } \\
\text { schooling }\end{array}$ & 20,102 & 42.5 & $42.1-43.0$ \\
\hline $\begin{array}{l}\text { High school } \\
\text { (incomplete/ } \\
\text { complete) }\end{array}$ & 5,254 & 11.1 & $10.8-11.4$ \\
\hline $\begin{array}{l}\text { College } \\
\text { (incomplete/ } \\
\text { complete) }\end{array}$ & 1,706 & 3.6 & $3.4-3.8$ \\
\hline $\begin{array}{l}\text { Unknown/no } \\
\text { data }\end{array}$ & 16,126 & 34.1 & - \\
\hline
\end{tabular}

Source: SINAN-MG (Brazilian Case Registry DatabaseMinas Gerais).
In 37,044 cases (78.3\%), TST was not performed. Considering the total number of cases, the TST results were as follows: negative, in 5.4\%; weakly positive, in 1.9\%; and strongly positive, in $11.6 \%$ (Table 2).

The pulmonary, extrapulmonary, and disseminated forms of tuberculosis were found in 39,669 (83.9\%), 8,509 (18.0\%), and 1,973 $(4.2 \%)$ of the cases, respectively. Among the patients with pulmonary tuberculosis, 33,505 $(80.5 \%)$ of the 41,642 results were positive on the first and second smears, confirming the diagnosis of the pulmonary form of the disease, and, for those under 15 years of age, the proportion was $6.9 \%(479 / 6,989)$. Overall, the most common comorbidity was alcoholism, in 8,112 cases (17.2\%), followed by HIV infection, in 3,915 (8.3\%), and DM, in 1,786 (3.8\%). Comorbidity of pulmonary tuberculosis with alcoholism, HIV infection, and DM was identified in $15.0 \%, 4.5 \%$, and $3.2 \%$ of the cases, respectively.

According to the data collected from the SINAN, outcomes were as follows: cure, in 34,611 cases (73.1\%); treatment noncompliance, in 5,311 cases $(11.2 \%)$; transfer, in 2,558, (5.4\%); a change in diagnosis, in 1,334 (2.8\%); MDR tuberculosis, in $79(0.2 \%)$; and no data/unknown, in 2,715 (5.7\%; Figure 3). A total of 677 deaths were reported, and the mortality rate was $3.5 \%$ (677/19,220,578).

According to data collected from the SIM, there were 2,488 deaths from tuberculosis, of which $2,215(89.0 \%)$ were from pulmonary tuberculosis, 143 (5.8\%) were from miliary tuberculosis, 58 (2.3\%) were from central nervous

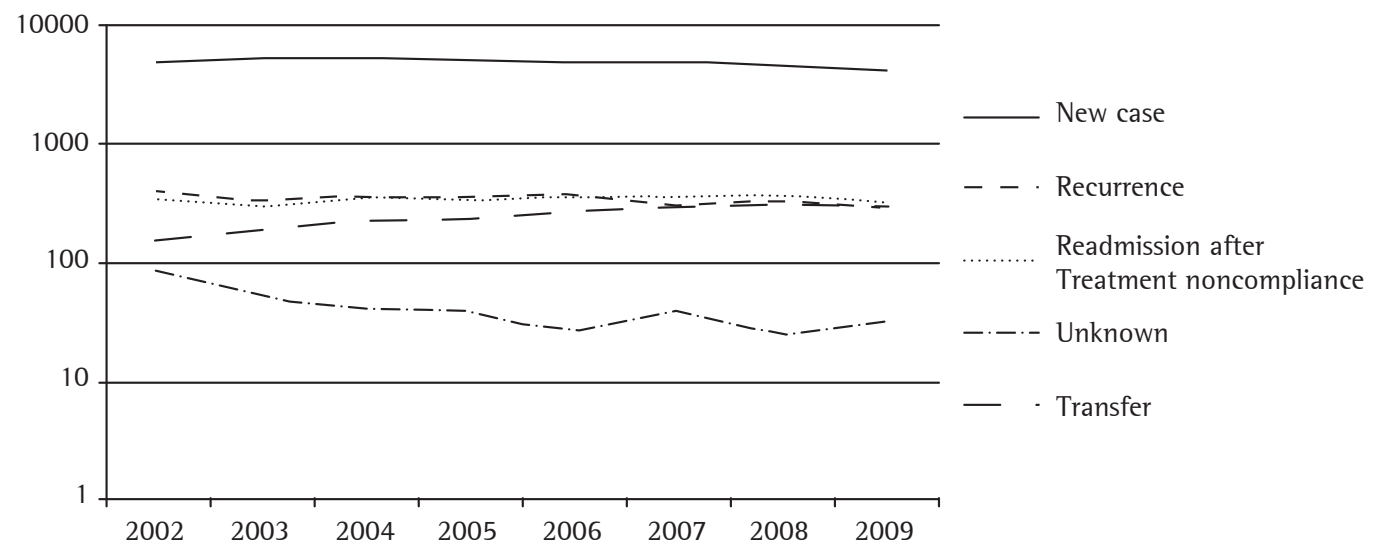

Figure 2 - Profile of tuberculosis by type of admission, Minas Gerais, Brazil, 2002-2009. Source: SINAN-MG (Brazilian Case Registry Database-Minas Gerais). Number of cases on a logarithmic $\left(\log _{10}\right)$ scale. 
Table 2 - Frequency of testing among the cases diagnosed with tuberculosis, Minas Gerais, Brazil, 2002-2009.

\begin{tabular}{|c|c|c|c|}
\hline Test & $n$ & $\%$ & $95 \% \mathrm{Cl}$ \\
\hline \multicolumn{4}{|l|}{ 1st sputum smear } \\
\hline Positive & 25,461 & 53.8 & $53.4-54.3$ \\
\hline Negative & 9,497 & 20.1 & $19.7-20.4$ \\
\hline Not performed & 12,323 & 26.1 & $25.7-26.5$ \\
\hline Unknown/no data & 4 & - & - \\
\hline \multicolumn{4}{|l|}{ 2nd sputum smear } \\
\hline Positive & 6,077 & 27.3 & $26.7-27.9$ \\
\hline Negative & 3,236 & 14.5 & $14.1-15.0$ \\
\hline Not performed & 12,943 & 58.1 & $57.5-58.8$ \\
\hline Unknown/no data & 25,029 & - & - \\
\hline \multicolumn{4}{|l|}{ Sputum culture } \\
\hline Positive & 2,743 & 5.8 & $5.6-6.0$ \\
\hline Negative & 1,370 & 2.9 & $2.7-3.0$ \\
\hline In progress & 1,941 & 4.1 & $3.9-4.3$ \\
\hline Not performed & 41,227 & 87.2 & $86.9-87.5$ \\
\hline Unknown/no data & 4 & - & - \\
\hline \multicolumn{4}{|l|}{ Chest X-ray } \\
\hline Suspicious & 38,495 & 82.3 & $81.9-82.6$ \\
\hline Normal & 3,284 & 7.0 & $6.8-7.2$ \\
\hline $\begin{array}{l}\text { Pathologies other } \\
\text { than tuberculosis }\end{array}$ & 564 & 1.2 & $1.1-1.3$ \\
\hline Not performed & 4,453 & 9.5 & $9.2-9.8$ \\
\hline Unknown/no data & 489 & - & - \\
\hline \multicolumn{4}{|l|}{ Tuberculin skin test } \\
\hline Negative & 2,551 & 5.5 & $5.3-5.7$ \\
\hline Weakly positive & 904 & 1.9 & $1.8-2.1$ \\
\hline Strongly positive & 5,485 & 11.9 & $11.6-12.2$ \\
\hline Not performed & 37,044 & 80.6 & $80.2-80.9$ \\
\hline Unknown/no data & 1,301 & - & - \\
\hline
\end{tabular}

Source: SINAN-MG (Brazilian Case Registry DatabaseMinas Gerais). system tuberculosis, and $72(2.9 \%)$ were from tuberculosis in other organs. The mortality rate was $12.9 \%(2,488 / 19,220,578)$.

\section{Discussion}

The mean incidence (defined on the basis of the reported cases alone) in the state of Minas Gerais for the study period was 22.3/100,000 population, which means that Minas Gerais ranks 24th among the Brazilian states ${ }^{(13)}$ and has met the millennium development goal for tuberculosis incidence, which is to reduce incidence to 25.6 cases per 100,000 population by 2015..$^{(13)}$ However, an analysis of the distribution of the disease by city reveals a different scenario, since 92 cities had incidence rates equal to or greater than the national average of 38.3/100,000 population. This demonstrates that, in the state of Minas Gerais, prioritization should not be restricted to the metropolitan areas singled out by the tuberculosis control program, given that high incidence rates are found in smaller cities.

In the present study, tuberculosis predominated in the economically active population (i.e., those aged 20-49 years) and in individuals over 65 years of age, especially in males, at a ratio of $2: 1$, with a low level of education, which is in agreement with the findings of other studies. ${ }^{(2,13)}$

Regarding the type of admission, new cases accounted for 83.7\%, and, as shown in Figure 2 , nearly all types of admission remained stable during the eight-year study period. In addition, it is of note that the calculated incidence is decreasing mainly because of the increase in the

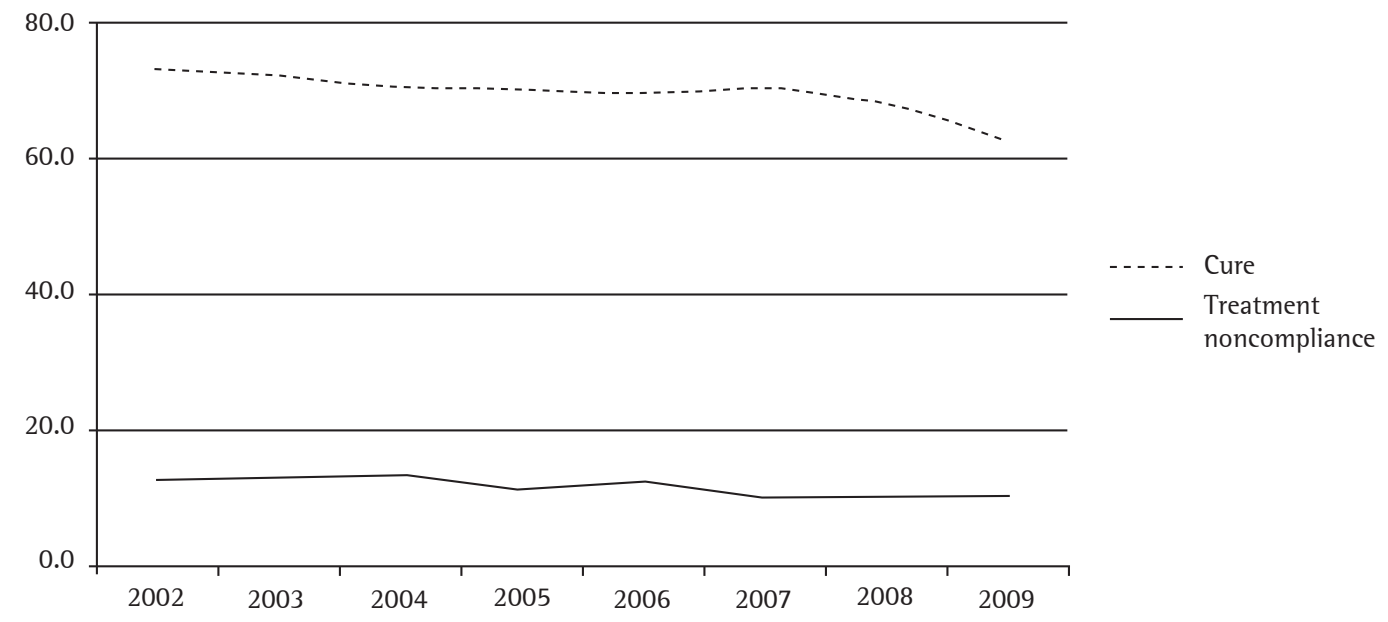

Figure 3 - Profile of tuberculosis by outcome (cure and treatment noncompliance), Minas Gerais, Brazil, 2002-2009. Source: SINAN-MG (Brazilian Case Registry Database-Minas Gerais). 
population, given that the absolute number of new cases has not decreased significantly over time. In order to reduce the number of new cases effectively, it is necessary to develop a process that can identify areas with different needs and measures, where the tuberculosis control program will invest in the surveillance of patients with respiratory symptoms and in the identification of the population at risk for latent tuberculosis. When such cases are identified and correctly treated, there will be a true reduction in the number of new cases.

For readmission after treatment noncompliance, the reported rate was only 5.7\%; however, the rate of treatment noncompliance during the study period was $11.2 \%$. This shows that the noncompliant patients did not return for another treatment. Active surveillance of these cases should be incorporated into the routine practice of the Family Health Program Teams.

The Brazilian National Tuberculosis Control Program, in accordance with the WHO recommendation, has set a target cure rate of 85\% and a target noncompliance rate of up to $5 \%$ for pulmonary tuberculosis. ${ }^{(2)}$ According to the reported tuberculosis outcomes in the state of Minas Gerais (Figure 3), little has been achieved in terms of cure (66.2\%) and noncompliance $(11.8 \%)$, which underscores the need for the implementation and expanded use of the DOTS strategy, the coverage of which was low. ${ }^{(13)}$

We found that approximately 30\% of the patients did not undergo sputum smear microscopy, which shows that this test is not routinely requested by health care workers. Since sputum smear microscopy is an inexpensive and easy-to-perform test that is needed for screening patients with respiratory symptoms, one realizes the ineffectiveness of the tuberculosis control measures, given that pulmonary tuberculosis was the most common form (in 84\%), as shown in other studies. ${ }^{(2)}$ Even for the patients who underwent the test, the positivity rate $(53.8 \%)$ is found to be lower than the 2009 nationwide rate (64\%), which underscores the need to implement quality control measures in the laboratories in the state of Minas Gerais. ${ }^{(2)}$

The results show that most patients did not undergo sputum culture (87.2\%). Although sputum culture is a more complex, more expensive test that takes longer to perform and is less accessible, it is of fundamental importance to the evaluation of smear-negative cases of pulmonary tuberculosis. Culture allows not only diagnosis but also mycobacterial identification and drug resistance determination, especially for patients with comorbidities, such as alcoholism, HIV infection, and DM. It is of fundamental importance to determine the resistance profile of the strains circulating in the state of Minas Gerais because of the high rate of noncompliance (11.9\%), primarily aiming at providing appropriate treatment. ${ }^{(4,9,10,13)}$ The low incidence of MDR tuberculosis $(0.2 \%)$ could be underestimated, given that most cases did not undergo sputum culture or susceptibility testing.

Chest X-ray, which is an extremely important tool in the investigation of pulmonary tuberculosis and in the identification of atypical presentations in immunocompromised patients, was the most commonly performed procedure (in 90.5\%). Suggestive findings are indispensable in order to request bacteriological examination (sputum smear microscopy and culture), ${ }^{(13)}$ which was not observed in this study, since sputum smear microscopy and culture were performed in only $73.9 \%$ and $12.9 \%$ of the cases, respectively. It should also be emphasized that a failure to perform culture precludes the correct identification of the bacterial species, as well as preventing the determination of drug resistance in order to define treatment.

In the study population, TSTs were requested in $80.6 \%$ of the cases and seem to have been used as a diagnostic parameter, given that bacteriological examination was not requested.

The high prevalence of comorbidities, such as alcoholism, HIV infection, and DM, shows the need for follow-up by a multidisciplinary team because of the possibility of a worsening of the diseases, as well as for measures, such as the DOTS strategy, at primary health care clinics in order to prevent noncompliance. . $^{(5-7,9,10)}$

Pulmonary tuberculosis was more common than was extrapulmonary tuberculosis when related to all comorbidities evaluated (alcoholism, HIV, and DM). Of those patients with pulmonary tuberculosis, $80.4 \%$ had two positive sputum smears, which shows the good sensitivity of sputum smear microscopy. However, for patients under 15 years of age, the positivity rate of sputum smear microscopy was only $6.8 \%$ of the cases of pulmonary tuberculosis, which might be related 
to smear-negative lesions and to the difficulty in expectorating. ${ }^{(8)}$

According to the reported data from the SIM and the SINAN, there was a large difference in terms of mortality (12.9\% vs. 3.5\%), which shows a large difference between the databases, justifying the need for measures that will enable data availability in a consistent and updated manner on the same platform automatically. Mortality is one of the main assessment measures of the tuberculosis control program, and the target set by the WHO is that mortality should be reduced to less than $5 \%$ by 2015 . Therefore, strategies should be developed to allow interaction between reporting programs, with cross-referencing of data, allowing improved data reliability.

Currently, epidemiological methods have been used for assessing the distribution of $M$. tuberculosis in a given community. These methods include the molecular biology techniques known as restriction fragment length polymorphism ${ }^{(14,15)}$ and mycobacterial interspersed repetitive units, ${ }^{(16,17)}$ which allow the assessment of recent infection (active surveillance) or late infection (surveillance of an at-risk population), as well as spoligotyping, which assesses the distribution of $M$. tuberculosis strains. ${ }^{(15,16)}$ Therefore, investments can be better targeted at the surveillance of individuals with respiratory symptoms or individuals with comorbidities who require preventive treatment of latent infection.

One of the limitations of this study was the use of secondary data, which might affect the quality of results. ${ }^{(18)}$

In conclusion, during the study period, the numbers of new cases, cases of treatment noncompliance, and deaths from tuberculosis were high, comorbidities were common, and there was a failure to perform basic tests for the adequate diagnosis of tuberculosis in the state of Minas Gerais. Therefore, it is necessary that there be a joint effort involving health care providers and administrators, as well as the civil society and its organized segments, in the fight against tuberculosis. In addition, expanded use of the DOTS strategy; management of tuberculosis/ HIV co-infection and MDR tuberculosis; and better knowledge of the distribution of the disease, with the improvement and combination of the data in the SIM and the SINAN; as well as epidemiological studies and studies on the molecular profiles of $M$. tuberculosis, are needed in order to achieve better control of the disease in the state of Minas Gerais.

\section{Acknowledgments}

We would like to thank the Graduate Program in Applied Health Sciences of the Federal University of Minas Gerais School of Medicine, the Fundação Ezequiel Dias (FUNED, Ezequiel Dias Foundation), and the Pulmonology Health Care Council of the Minas Gerais State Department of Health. We would also like to thank Professor Antonio Ruffino Netto for correcting the manuscript.

\section{References}

1. Pulmonar [homepage on the Internet]. São Paulo: Sociedade Paulista de Pneumologia e Tisiologia. Museu da Tuberculose. [cited 2011 Aug 25]. Available from: http://www.pulmonar.org.br/?op=paginasettipo=pagin actsecao $=9$ ctpagina $=111$

2. World Health Organization. Global Tuberculosis Control. Epidemiology, Strategy, Financing. Geneva: World Health Organization; 2010.

3. Instituto Brasileiro de Geografia e Estatística [homepage on the internet]. Brasília: Instituto Brasileiro de Geografia e Estatística. [cited 2011 Aug 25]. Available from: http:// www.ibge.gov.br/

4. Secretaria Estadual de Saúde de Minas Gerais [homepage on the Internet]. Belo Horizonte: Secretaria Estadual de Saúde. [cited 2011 Ago 25]. Available from: http:// www.saude.mg.gov.br

5. Prado TN, Caus AL, Marques M, Maciel EL, Golub JE, Miranda AE. Epidemiological profile of adult patients with tuberculosis and AIDS in the state of Espírito Santo, Brazil: cross-referencing tuberculosis and AIDS databases. J Bras Pneumol. 2011;37(1):93-9. http://dx.doi.org/10.1590/ S1806-37132011000100014 PMid:21390437

6. Boletim Epidemiológico - AIDS e DST. 27a - 52 a semanas epidemiológicas de julho a dezembro de $2007 ; 01^{\text {a }}-26^{\text {a }}$ - semanas epidemiológicas - janeiro a junho de 2008. Brasília: Ministério da Saúde; 2008.

7. Jeon $\mathrm{CY}$, Murray MB. Diabetes mellitus increases the risk of active tuberculosis: a systematic review of 13 observational studies. PLoS Med. 2008;5(7):e152. http:// dx.doi.org/10.1371/journal.pmed.0050152 PMid:18630984 PMCid:2459204

8. Faurholt-Jepsen D, Range N, Praygod G, Kidola J, Faurholt-Jepsen M, Aabye MG, et al. The role of diabetes co-morbidity for tuberculosis treatment outcomes: a prospective cohort study from Mwanza, Tanzania. BMC Infect Dis. 2012;12:165. http://dx.doi.org/10.1186/14712334-12-165 PMid:22839693 PMCid:3462148

9. Baker MA, Harries AD, Jeon CY, Hart JE, Kapur A, Lönnroth K, et al. The impact of diabetes on tuberculosis treatment outcomes: a systematic review. BMC Med. 2011;9:81. http://dx.doi.org/10.1186/1741-7015-9-81 PMid:21722362 PMCid:3155828

10. Caron-Ruffino M, Ruffino-Netto A. Association of alcoholism and pulmonary tuberculosis [Article in Portuguese]. Rev Saude Publica. 1979;13(3):183-94. http://dx.doi.org/10.1590/S0034-89101979000300003 PMid:542793 
11. Fundação Oswaldo Cruz. Escola Nacional de Saúde Pública Sergio Arouca. Educação a Distância. Controle da tuberculose: uma proposta de integração ensino serviço. Rio de Janeiro: EAD/ENSP, 2008 ;(3) 160.

12. Agresti A, Coull BA. Approximate is better than "exact" for interval estimation of binomial proportions. Am Stat. 1998;52(2):119-26.

13. Ministério da Saúde. Manual de Recomendações para o Controle da Tuberculose no Brasil. Brasília: Ministério da Saúde; 2010.

14. Thierry D, Brisson-Noël A, Vincent-Lévy-Frébault V, Nguyen S, Guesdon JL, Gicquel B. Characterization of a Mycobacterium tuberculosis insertion sequence, 1S6110, and its application in diagnosis. J Clin Microbiol. 1990;28(12):2668-73. PMid:2177747 PMCid:268253

15. van Embden JD, Cave MD, Crawford JT, Dale JW, Eisenach KD, Gicquel B, et al. Strain identification of Mycobacterium tuberculosis by DNA fingerprinting: recommendations for a standardized methodology.
J Clin Microbiol. 1993;31(2):406-9. PMid:8381814 PMCid:262774

16. Sola C, Filliol l, Legrand E, Lesjean S, Locht C, Supply P, et al. Genotyping of the Mycobacterium tuberculosis complex using MIRUs: association with VNTR and spoligotyping for molecular epidemiology and evolutionary genetics. Infect Genet Evol. 2003;3(2):125-33. http://dx.doi. org/10.1016/S1567-1348(03)00011-X

17. Supply P, Allix C, Lesjean S, Cardoso-Oelemann M, RüschGerdes S, Willery E, et al. Proposal for Standardization of Optimized Mycobacterial Interspersed Repetitive UnitVariable-Number Tandem Repeat Typing of Mycobacterium tuberculosis. J Clin Microbiol. 2006;44(12): 4498-4510. http://dx.doi.org/10.1128/JCM.01392-06 PMid:17005759 PMCid:1698431

18. Coeli CM. Sistemas de Informação em Saúde e uso de dados secundários na pesquisa e avaliação em saúde. Cad Saude Colet. 2010;18(3):335-6.

\section{About of the authors}

\section{Cláudio José Augusto}

Doctoral Student. Graduate Program in Applied Health Sciences, Federal University of Minas Gerais School of Medicine; and Researcher in Health and Technology. Fundação Ezequiel Dias - FUNED, Ezequiel Dias Foundation - Belo Horizonte, Brazil.

\section{Wânia da Silva Carvalho}

Associate Professor 1. Department of Social Pharmacy, Federal University of Minas Gerais School of Medicine, Belo Horizonte, Brazil.

\section{Alan Douglas Gonçalves}

Researcher in Health and Technology. Fundação Ezequiel Dias - FUNED, Ezequiel Dias Foundation - Belo Horizonte, Brazil.

\section{Maria das Graças Braga Ceccato}

Adjunct Professor 1. Department of Social Pharmacy, Federal University of Minas Gerais School of Medicine, Belo Horizonte, Brazil.

\section{Silvana Spindola de Miranda}

Associate Professor IV of Clinical Medicine/Pulmonology. Federal University of Minas Gerais School of Medicine, Belo Horizonte, Brazil. 